\title{
Antioxidative and Protective Activity of Polysaccharide Extract from Artemisia iwayomogi Kitamura Stems on UVB-Damaged Mouse Epidermis
}

\author{
Byung Yong Ahn ${ }^{1 *}$ and Mun Yhung Jung ${ }^{2}$ \\ ${ }^{1}$ Department of Oriental Medicine Resources, Chonbuk National University, Iksan, Jeonbuk 570-752, Republic of Korea \\ ${ }^{2}$ College of Food Science, Woosuk University, Wanju, Jeonbuk 565-701, Republic of Korea
}

Received July 15, 2011; Accepted August 31, 2011

\begin{abstract}
Polysaccharide (PS) was fractionated from hot-water extract of Artemisia iwayomogi Kitamura stems. PS showed considerably higher hydroxyl radical scavenging activity than caffeic acid and glutathione. PS showed lower superoxide anion radical scavenging activity than hydroquinone and ascorbic acid. The scavenging activity of PS on the reactive oxygen species (ROS) induced by human neutrophils with zymosan was determined by the lucigenin-enhanced chemiluminescence assay. The scavenging effect of the PS on ROS as determined by the chemiluminescence assay was about 2-fold stronger than that of ascorbic acid at the same concentration. PS significantly decreased protein carbonyl and malonaldehyde contents in UVB irradiated skin homogenates, which was comparable to glutathione at the same concentration. This result suggested that PS derived from $A$. iwayomogi Kitamura stems may be a potent candidate as functional compound for the protection on UVB induced skin damage in cosmetics.
\end{abstract}

Key words: Artemisia iwayomogi Kitamura, polysaccharide, reactive oxygen species, skin damage, ultraviolet B

\section{Introduction}

Reactive oxygen species (ROS) generated by sunlight, ionizing radiation, chemical reactions and metabolic processes may lead to a variety of pathological consequences such as DNA damage, carcinogenesis, cellular degradation related to aging, and damage to the immune system [Darr and Fridovich, 1994]. Skin, in particular upon UV irradiation, seems to be extremely susceptible to free radicals-induced oxidative damages [Korytoski et al., 1987]. The term ROS collectively includes oxygen-centered radicals such as the superoxide anion $\left(\mathrm{O}_{2}^{-}\right)$, the hydroxyl radical $\left(\mathrm{HO}^{-}\right)$, and non-radical species such as singlet oxygen and hydrogen peroxide.

Antioxidants have been considered to be physiologic photoprotective compounds against the ROS induced skin damages [Romero-gillette et al., 1996]. Plant polysaccharides (PS) have exhibited strong antioxidative properties and can be explored as novel potential antioxidants [Ramarahnam et al., 1995; Hu et al., 2003; Wang and Luo, 2007]. The Oriental medicinal plants "Injinho", Artemisia capillaris THUNB and "Injinssuk" Artemisia iwayomogi Kitamura, have been traditionally used for treating liver disease without special

*Corresponding author

Phone: +82-63-850-0743; Fax: +82-63-850-0741

E-mail:ahn2002@jbnu.ac.kr

http://dx.doi.org/10.3839/jabc.2011.031 distinction because of the similarity of plant origin, but "Injinssuk" A. iwayomogi Kitamura is mainly used in Korea [Lee et al., 1997]. The active components in the A. iwayomogi have been reported as low molecular compounds including esculetin 6-methylether, esculetin 7-methylether (scopoletin), scopolin, beta-sitosterol, chlorogenic acid, essential oil, fatty acid, sesquiterpene lactones, eudesmanolides, and flavonoids [Yook, 1989]. Song [1996] reported, however, that PS extract of A. iwayomogi Kitamura showed especially strong antihepatotoxic activities. Koo et al. [1994] reported that PS fraction obtained from $A$. iwayomogi Kitamura showed immunomodulation and anti-tumor activity in mice. Ahn et al. [2009] reported recently that the ethanol insoluble part among the water extracts of $A$. iwayomogi Kitamura had the strong inhibitory effect against the mutagenicity of benzo[a]pyrene conversed by a mixed-function oxidase system to an ultimate metabolite. The activity of PS fraction of $A$. iwayomogi Kitamura might be related, at least to some extent, to its ROS scavenging activity. Since $A$. iwayomogi Kitamura is one of woody plants, its stem consists of the major portion of this plant. Only leaves of $A$. iwayomogi Kitamura are mainly used for the medicinal purpose. In our preliminary experiment, it was found that its stem contains higher amount of PS than leaves. However, the ROS scavenging activity of PS extract of $A$. iwayomogi Kitamura stem has not been systematically studied in biological model systems. The protective activity of the PS extract of $A$. iwayomogi Kitamura stems against UVB damage of skin tissue 
has also never been previously studied.

The objectives of this study were to study (A) the scavenging activities of PS obtained from A. iwayomogi Kitamura stem on the hydroxyl radical and superoxide anion, (B) the scavenging activity of the PS on the ROS induced in human neutrophils stimulated with unopsonized zymosan by the lucigeninenhanced chemiluminescence assay, and (C) the protective effect of the PS on skin damage induced by UV using a mouse skin model obtained from mice fed vitamin $\mathrm{E}$ deficient diet.

\section{Materials and Methods}

Materials. A. iwayomogi Kitamura stems were collected in a local farm, located in Jinan, Republic of Korea, on May, 2007. Ascorbic acid, ethanol (99.8\%), glutathione, nitroblue tetrazolium (NBT), riboflavin, cytochrome c, lucigenin, zymosan, and RPMI1640 were purchased from Sigma Chemical Co. (St. Louis, MO).

Extraction and fractionation of PS. Extraction of PS from the stems of $A$. iwayomogi Kitamura was performed according to the previously reported method [Lee et al., 1997]. Dried and ground stem of $A$. iwayomogi Kitamura were first socked in ethanol $(99.8 \%)$ for $24 \mathrm{~h}$ at $37^{\circ} \mathrm{C}$ and then the ethanol extract was discarded to remove low molecular weight components. After drying at $45^{\circ} \mathrm{C}$, the stems were further extracted with hot water for $5 \mathrm{~h}$ at $70^{\circ} \mathrm{C}$ twice and the water extract was freezedried. The supernatant obtained by centrifugation at $6,000 \mathrm{rpm}$ for $20 \mathrm{~min}$ after soaking the freeze-dried powder in $75 \%$ ethanol for $12 \mathrm{~h}$ at $4^{\circ} \mathrm{C}$ was filtered with a filter paper (Whatman No. 2) and evaporated under vacuum, and then freeze-dried again to obtain non-PS (NPS) portion. PS portion was obtained by freeze-drying the residue.

Hydroxyl radical scavenging activity. The hydroxyl radicals were generated in L-ascorbic acid-CuSO${ }_{4}$ system by reduction of $\mathrm{Cu}^{2+}$ and were assayed by the oxidation of cytochrome $\mathrm{c}$ [Liu and $\mathrm{Ng}, 2000]$. In this experiment, the hydroxyl radicals were generated in $3 \mathrm{~mL}$ of $0.15 \mathrm{mM}$ sodium phosphate buffer $(\mathrm{pH}$ 7.4), containing $100 \mu \mathrm{M}$ L-ascorbic acid, $100 \mu \mathrm{M} \mathrm{CuSO}$, $12 \mu \mathrm{M}$ cytochrome c, and 25,50 , or $100 \mu \mathrm{g}$ antioxidants or PS, respectively. The mixture was incubated at $25^{\circ} \mathrm{C}$ for $90 \mathrm{~min}$. The change in transmittance caused by the color change of cytochrome c was measured at $550 \mathrm{~nm}$. The hydroxyl radical quenching ability was calculated by determining the inhibition of the color changes.

Superoxide radical scavenging activity. Superoxide quenching activities of samples, hydroquinone, L-ascorbic acid and glutathione were determined photochemically, using the assay system consisting of methionine, riboflavin, and NBT [Ginnopolitis and Ries, 1977]. The reaction mixture was composed of $1.3 \mathrm{mM}$ riboflavin, $13 \mathrm{mM}$ methionine, $0.63 \mathrm{M}$
NBT, 0.05 M sodium carbonate ( $\mathrm{pH}$ 10.2), and antioxidant or PS. Three $\mathrm{mL}$ of the mixture was transferred, in triplicate, into a transparent glass serum bottle. The sample tubes were randomly placed in a light storage box and replaced randomly for $10 \mathrm{~min}$ as previously described in detail [Jung et al., 1995]. The temperature within the light storage box was 20 during light illumination. The light intensity at the sample level was 5500 Lux. During the light illumination, NBT was reduced to blue formazan by the superoxide anion formed. The blue formazan formation was determined by measuring the absorbance at 560 $\mathrm{nm}$. The inhibition of blue formazan formation was expressed as superoxide quenching activity.

Chemiluminescence assay for the detection of reactive oxygen species (ROS). Human neutrophils were isolated according to Lindena and Burkhardt [Lindena and Burkhardt, 1988]. Chemiluminescence assay was conducted according to the previously reported method [Blair et al., 1988; Boudard et al., 1994]. The treated amount of antioxidant or PS was $20 \mu \mathrm{g}$ per well. Lucigenin was used as an enhancer. Human neutrophils (approximately $1 \times 10^{6}$ cells/well) were plated in 96 well plates. Then, $50 \mu \mathrm{L}$ of luminol and lucigenin were added per well of a white 96-well plate [Blair et al., 1988; Boudard et al., 1994]. After incubation of the well plate at $37^{\circ} \mathrm{C}$ in the dark for $15 \mathrm{~min}$, $30 \mu \mathrm{L}$ of zymosan solution was added. Chemiluminescence emitted from each of the wells was immediately measured as relative light units $(\mathrm{RLU})$ at $37^{\circ} \mathrm{C}$ in the dark for $65 \mathrm{~min}$ at $5 \mathrm{~min}$ intervals using a luminometer (Berthold 96LP, Pforzheim, Germany). The chemiluminescence response was quantified as an integrated area (IA) below the resulting chemiluminescence curve during a period of 0 to $65 \mathrm{~min}$. For the calculation of ROS scavenging activity, total chemiluminescences for control and sample were obtained by the adding up the chemiluninescence response at each time during $65 \mathrm{~min}$. The inhibitory effects of samples on the chemiluminescence response are represented as $\%$ inhibition $=[1(\mathrm{IA}$ for sample - blank $) /(\mathrm{IA}$ for control blank)] $\times 100$.

Feeding of an experimental animal and sample collection. ICR mice (10-14 g) aged 3 weeks were purchased from Hyochang Science (Daegu, Korea) as an experimental animal and it was fed with vitamin E-deficient diet for 10 weeks after adjusting to a new environment for 7 days with eating commercialized solid feed. After the mouse was anesthetized with dry ice, its hair was shaved with an electric shaver. Then tissues including epidermis and dermis were collected from it. The samples were washed with $0.9 \%$ saline to remove remaining hairs and blood and eliminate water with filter papers. The skin tissues were stored at $-70^{\circ} \mathrm{C}$ and used for this study.

Preparing a skin homogenate. The skin tissues were homogenized after adding $1.15 \% \mathrm{KCl}$ solution (1:10, v/v). Two $\mathrm{mL}$ homogenate was transferred into a petri dish $(3 \mathrm{~cm}$ in 
diameter). At this time, the PS, vitamin $\mathrm{C}$, or glutathion solutions was prepared at the concentration of $0.05 \mathrm{~g} / \mathrm{mL}$, and then $50 \mu \mathrm{L}$ of the prepared solution was added to each petri dish. Then, the samples were exposed to UVB (280-320 nm) by using a UV radiator (National biological corporation, Beachwood, $\mathrm{OH}$ ) for 30 and $60 \mathrm{~min}$ at the $1.0 \mathrm{~mW} / \mathrm{cm} / \mathrm{sec}$ of UVB irradiation dosage.

Determination of protein carbonyl content. Protein carbonyl content was measured by the previously reported method [Oliver et al., 1987] using dinitrophenylhydrazine (2,4DNPH). The skin tissues were divided into three equal aliquots containing approximately $1.0 \mathrm{mg}$ of protein each. Three samples were precipitated with $20 \%$ trichloroacetic acid $(\mathrm{w} / \mathrm{v}$, final concentration). One sample was treated with $2 \mathrm{~N} \mathrm{HCl}$, and the other sample was treated with an equal volume of $0.2 \%(\mathrm{w} / \mathrm{v})$ precipitated with 2,4-DNPH in $2 \mathrm{~N} \mathrm{HCl}$. The samples were incubated at $25^{\circ} \mathrm{C}$ and stirred at $5 \mathrm{~min}$ intervals. The samples were then reprecipitated with $20 \%$ trichloroacetic acid and subsequently extracted with ethanol: ethyl acetate $(1: 1, \mathrm{v} / \mathrm{v})$ and then reprecipitated at $10 \%$ trichloroacetic acid. The pellets were carefully drained and dissolved in $6 \mathrm{M}$ guanidine $\mathrm{HCl}$ solution and estimated by the absorbance at $370 \mathrm{~nm}$.

Measurement of lipid peroxidation. The level of lipid peroxidation in skin tissues was measured by the previously reported method [Ohkawa et al., 1979]. Twenty percent (w/v) tissue homogenate was mixed with sodium dodecyl sulfate, acetate buffer $(\mathrm{pH} 3.5)$ and aqueous solution of thiobarbituric acid. After heating at $95^{\circ} \mathrm{C}$ for $60 \mathrm{~min}$, cool completely in a cold water, add $1 \mathrm{~mL}$ distilled water and $5 \mathrm{~mL} n$-butanol: pyridine mixture $(15: 1, \mathrm{v} / \mathrm{v})$ and vortex them at 4,000 rpm. After then, divided organic solvent phase was collected and estimated by the absorbance at $532 \mathrm{~nm}$. As an external standard, 1,1,3,3tetramethoxypropane was used, and lipid peroxide level was expressed in terms of nmol malondialdehyde.

Statistical analysis. The data were analyzed with the SPSS software package (SPSS ver. 12, Chicago, IL). The significance among data were determined by Duncan's multiple range test at $p<0.05$.

\section{Results and Discussion}

Hydroxyl and superoxide radical quenching activity of PS. A. iwayomogi Kitamura (Korean medicinal plant) has been traditionally used for treating liver diseases in Korea. In our previous report, it was confirmed that the effective component for the inhibitory effects of $A$. iwayomogi Kitamura on melanin biosynthesis was its PS [Chun et al., 2001]. In this present work, we would like to see whether its PS obtained from A. iwayomogi Kitamura stems was effective for the scavenging activities of reactive oxygen species. Different ROS such as peroxy, alkoxy, hydroxyl, and superoxide anion radicals are not equally reactive
Table 1. Hydroxyl radical scavenging activity of PS fraction of water extracts of $A$. iwayomogi Kitamura stems

\begin{tabular}{cccc}
\hline \hline Samples & Conc. (mg/assay) & $\begin{array}{c}\text { Transmittance } \\
(550 \mathrm{~nm})\end{array}$ & Inhibition (\%) \\
\hline Control & - CuSO $_{4}$ & $59.4 \pm 0.40$ & \\
$\mathrm{OH}^{-}$ & Buffer & $78.6 \pm 0.45$ & \\
\hline \multirow{2}{*}{ Caffeic acid } & 100 & $75.1 \pm 0.05^{\mathrm{b}}$ & $18.23^{\mathrm{b}}$ \\
& 500 & $60.1 \pm 0.02^{\mathrm{a}}$ & $96.35^{\mathrm{a}}$ \\
\hline \multirow{3}{*}{ Glutathione } & 25 & $78.8 \pm 0.20^{\mathrm{c}}$ & $-1.04^{\mathrm{c}}$ \\
& 50 & $75.6 \pm 0.62^{\mathrm{ab}}$ & $15.62^{\mathrm{ab}}$ \\
& 100 & $74.5 \pm 0.70^{\mathrm{a}}$ & $21.35^{\mathrm{a}}$ \\
\hline & 25 & $75.4 \pm 0.41^{\mathrm{c}}$ & $15.63^{\mathrm{c}}$ \\
& 50 & $71.5 \pm 0.30^{\mathrm{b}}$ & $36.97^{\mathrm{b}}$ \\
& 100 & $65.9 \pm 0.52^{\mathrm{a}}$ & $66.14^{\mathrm{a}}$ \\
\hline
\end{tabular}

The hydroxyl radicals were generated in $3 \mathrm{~mL}$ of $0.15 \mathrm{mM}$ sodium phosphate buffer (pH 7.4), containing $100 \mu \mathrm{M}$ L-ascorbic acid, $100 \mu \mathrm{M}$ $\mathrm{CuSO}_{4}, 12 \mu \mathrm{M}$ cytochrome $c$ and $25,50,100 \mu \mathrm{g}$ samples, respectively. The values of optical density (O.D) are mean $\pm \mathrm{SD}$ of 3 experiments. Different letters within the same row are significantly different at $p<0.05$ as determined by Duncan's multiple range tests.

Table 2. Superoxide radical quenching ability of PS fraction of water extract of $A$. iwayomogi Kitamura stems

\begin{tabular}{cccc}
\hline \hline Samples & Conc. (mg/assay) & O.D. $(560 \mathrm{~nm})$ & Inhibition (\%) \\
\hline Control & & $0.223 \pm 0.007$ & \\
\hline \multirow{3}{*}{ Hydroquinone } & 25 & $0.005 \pm 0.000^{\mathrm{b}}$ & $97.75^{\mathrm{b}}$ \\
& 50 & $0.001 \pm 0.000^{\mathrm{a}}$ & $99.55^{\mathrm{a}}$ \\
\hline \multirow{3}{*}{ Ascorbic acid } & 100 & $0.001 \pm 0.000^{\mathrm{a}}$ & $99.55^{\mathrm{a}}$ \\
& 25 & $0.051 \pm 0.001^{\mathrm{b}}$ & $77.13^{\mathrm{b}}$ \\
& 50 & $0.050 \pm 0.002^{\mathrm{b}}$ & $77.57^{\mathrm{b}}$ \\
& 100 & $0.001 \pm 0.000^{\mathrm{a}}$ & $99.55^{\mathrm{a}}$ \\
\hline \multirow{3}{*}{ Glutathione } & 25 & $0.250 \pm 0.002^{\mathrm{a}}$ & $-12.55^{\mathrm{a}}$ \\
& 50 & $0.254 \pm 0.004^{\mathrm{a}}$ & $-13.90^{\mathrm{a}}$ \\
& 100 & $0.263 \pm 0.002^{\mathrm{b}}$ & $-15.93^{\mathrm{b}}$ \\
\hline PS & 25 & $0.116 \pm 0.005^{\mathrm{c}}$ & $40.81^{\mathrm{c}}$ \\
& 50 & $0.088 \pm 0.004^{\mathrm{b}}$ & $55.10^{\mathrm{b}}$ \\
& 100 & $0.050 \pm 0.006^{\mathrm{a}}$ & $74.40^{\mathrm{a}}$ \\
\hline
\end{tabular}

The reaction mixture was composed of $1.3 \mathrm{mM}$ riboflavin, $13 \mathrm{mM}$ methionine, 0.63 M NBT, $0.05 \mathrm{M}$ sodium carbonate ( $\mathrm{pH} 10.2)$, and test sample or antioxidants. The light intensity was 5,500 Lux. The values of optical density (O.D) are mean \pm SD of 3 experiments. Different letters within the same row are significantly different at $p<0.05$ as determined by Duncan's multiple range tests.

to the molecules in biological systems [Yen and Duh, 1996]. In this present study, hydroxyl and superoxide radical scavenging activities of PS were determined along with caffeic acid (a known effective hydroxyl radical scavenger), hydroquinone acid (a known effective superoxide radical quencher), and ascorbic acid and glutathione (well known effective antioxidants) [Choi et al., 2001]. At a concentration of $100 \mathrm{mg}$ per $3 \mathrm{~mL}$, caffeic acid, glutathione and PS scavenged 18.23, 21.35, and 66.14\% of hydroxyl radical produced in L-ascorbic acid- $\mathrm{Cu}_{2}$ system (Table $1)$, respectively.

PS showed $66.14 \%$ hydroxyl radical scavenging activity, 
showing the highest scavenging activity among the tested samples for hydroxyl radicals produced in L-ascorbic acid- $\mathrm{Cu}_{2}$ system (Table 1). Note that the caffeic acid, a known strong hydroxyl radical scavenger, showed only $18.23 \%$ hydroxyl radical scavenging activity at the same concentration $(100 \mathrm{mg} /$ assay). As shown in Table 2, the superoxide anion quenching abilities of hydroquinone, ascorbic acid, glutathione and PS at concentration of $100 \mathrm{mg}$ per $3 \mathrm{~mL}$ were 99.55, 99.55, -15.93, and $74.40 \%$, respectively. Compared with hydroquinone and ascorbic acid, PS was less effective. It is interesting to note that the addition of glutathione did not show the superoxide radical scavenging activity. This result clearly showed that PS extract of A. iwayomogi Kitamura stem exceptionally strong scavenged hydroxyl radical, and had a considerable scavenging activity on superoxide radicals.

Effect of PS on ROS production in human neutrophils. The inhibitory effects of ascorbic acid, glutathione and PS on reactive oxygen species (ROS) production in human neutrophils stimulated with unopsonized zymosan was shown as Fig. 1. The inhibitory effects of ascorbic acid, glutathione and PS on ROS production in human neutrophils were 44.52, -41.07 , and $83.14 \%$ at concentration of $20 \mu \mathrm{g}$ per well, respectively. ROS production in human neutrophils kinetically peaked at $20 \mathrm{~min}$ after unopsonized zymosan treatment and then decreased gradually. The peak of ROS production in human neutrophils treated with PS was at 10 min zymosan treatment. Total luminescence detected in control during 0-65 min was 23090 $\left(\mathrm{RLU}, \times 10^{-3}\right)$. The luminescence detected in sample treated with ascorbic acid, glutathione, and PS were, 13067, 33034, and 3917 $\left(\mathrm{RLU}, \times 10^{-3}\right)$, respectively. Total luminescence detected in blank (without zymosan treatment) during 0-65 min was 290 (RLU, $\left.\times 10^{-3}\right)$, indicating the requirement of zymosan for the ROS production. PS had the greatly higher ROS scavenging activity than ascorbic acid at the same concentration. The inhibitory effect of ascorbic acid and PS on total ROS production was 44 and $84 \%$, respectively. Glutathione did not show any scavenging activity on ROS in the lucigenin enhanced chemiluminescence assay (Fig. 1). In cellular oxidation reactions, superoxide radical is normally formed first, and its effects can be magnified because it produces other kinds of cell-damaging free radicals and oxidizing agents. Lucigenin was used as an enhancer because lucigenin is known to interact predominantly with superoxide anion [Mills et al., 1980] in the chemiluminescene assay. It has been reported that superoxide anion radical is a strong inducer for inflammatory processing in biological system [Aeschbacher, 1990]. Thus, the anti-inflammatory activity of $A$. iwayomogi Kitamura reported earlier [Yook, 1989] might be partly explained by its strong superoxide anion scavenging activity. The pro-oxidant effect of glutathione on ROS production in chemiluminesence assay was consistent with the

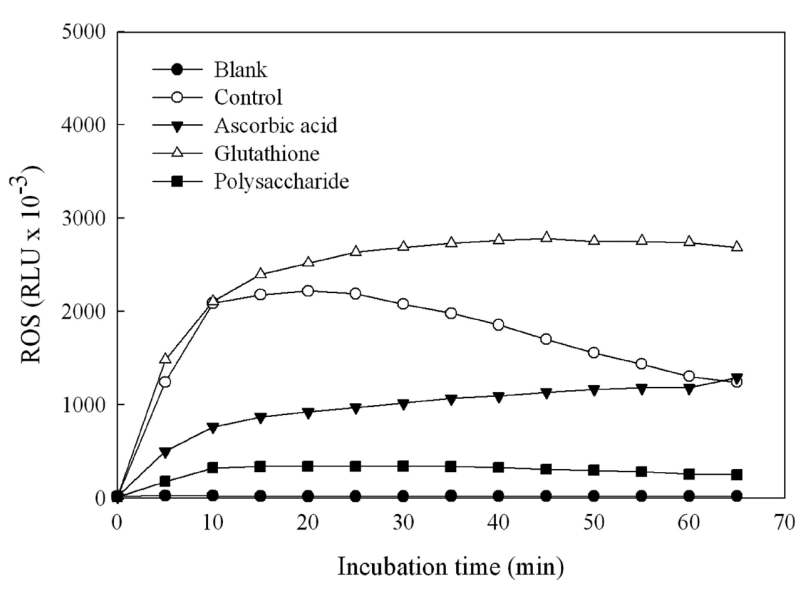

Fig. 1. Inhibition effect of PS obtained from $A$. iwayomogi Kitamura stems on ROS production. The control is treated with unopsonizied zymosan only. The treated amount of antioxidant or PS was $20 \mathrm{mg}$ per well.

result obtain in superoxide anion scavenging activity assay in Table 2. It has been previously reported that PSs obtained from various mushrooms had scavenging activity of superoxide and hydroxyl radicals [Sakagami et al., 1991; Liu and Ng, 2000]. Also, low molecular compounds such as chlorogenic acid as antioxidant constituent of $A$. iwayomogi Kitamura have been reported [Kim et al., 1997]. In this experiment, we remove the low molecular compounds with ethanol before extracting the PS. Further purification was performed with ethanol again after extracting with hot water. Thus it could be excluded that chlorogenic was an antioxidant component in the PSs used in this study. This present result strongly suggested that PS extracted from A.iwayomogi Kitamura stems possessed strong ROS scavenging activity.

Effect of PS on UVB induced mouse skin damage. UV radiation is known to exert production of various different types of reactive oxygen species which could lead to cell damage (2). Reactive oxygen species (ROS) may be a common intermediated step in the processes that initiated tissue damage leading to the damage of DNA and other major cellular targets [Dvies and Goigberg, 1987]. Since PS obtained from $A$. iwayomogi Kitamura stem showed strong scavenging activity of ROS, the PS may be possible a protective agent against UVB induced skin damage. Thus, we studied the effects of PS obtained from A.iwayomogi Kitamura stem on the formation of oxidized proteins and lipid peroxide in animal skin tissues induced by UVB irradiation (Fig. 2, 3). After the UVB irradiation on skin homogenates with no antioxidant treatment (control) for 30 and $60 \mathrm{~min}$, the contents of protein carbonyl increased from 5.96 to 19.9 , and $35.1 \mathrm{nmol}$ per mg protein, respectively. The result showed that UVB greatly induced the protein oxidation in the skin homogenates, indicating the induction of cellular damages by UVB irradiation. However, the 


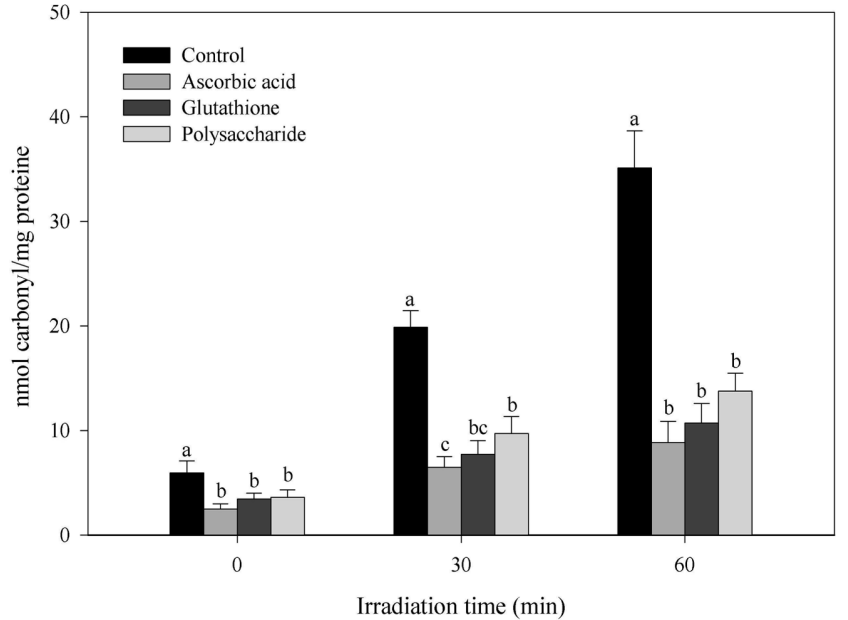

Fig. 2. Protein carbonyl values in UVB irradiated skin homogenates of mice fed vitamin $\mathbf{E}$ deficient diet. Values represent the mean $\pm \mathrm{SD}$ of three replications, and significant differences of samples were determined by Duncan's multiple test at the level of $p \leq 0.01$. The treated amount of antioxidant or PS was $2.5 \mathrm{mg}$ per petridish.

ascorbic acid, glutathione and PS treatment greatly decreased the formation of protein carbonyl in skin homogenates after UVB irradiation for 30 and $60 \mathrm{~min}$. The carbonyl contents in skin homogenates treated with ascorbic acid, glutathione, and PS after $60 \mathrm{~min}$ UVB irradiation were 8.56, 10.70, and $13.78 \mathrm{nmol}$ per mg protein, respectively (Fig. 2). It has been previously reported that combination treatment of vitamin $\mathrm{C}$ and $\mathrm{E}$ showed UVB photoprotection in pig skins [Zhou et al., 2008]. Our results showed that ascorbic acid (vitamin $\mathrm{C}$ ) alone protect the mouse skin damage induced by UVB irradiation. The protective effect of PS on protein oxidation was slightly lower than those of ascorbic acid and glutathione. Still the inhibitory effect of PS against protein oxidation in skin induced by UVB irradiation was considerable. Note that the carbonyl contents in skin homogenates of control (no treatment) and PS treated sample were 35.1 and $13.78 \mathrm{nmol}$ per mg protein, respectively. The PS treated sample showed only $39.3 \%$ of the carbonly content as compared to control after $60 \mathrm{~min}$ UVB irradiation. Our result was in consistent with the previous report obtained from other source of polysaccarides. It has been previously that PS of Tamarindus indica showed protecitve activity on cornealderived cells (SIRC) damages induced by UVB radiation [Raimondi et al., 2003].

The ascorbic acid, glutathione and PS showed great activities on the lipid peroxidation as shown in Fig 3. The UVB irradiation on skin homogenates with no antioxidant treatment (control) for 30 and $60 \mathrm{~min}$ increased the malondialdehyde contents from 0.73 to 1.58 and $2.27 \mathrm{nmol}$ per mg protein, respectively. The result showed that UVB greatly induced the lipid oxidation in the skin homogenates. The malondialdehyde contents in the control, ascorbic acid, glutathione, and PS groups exposed to

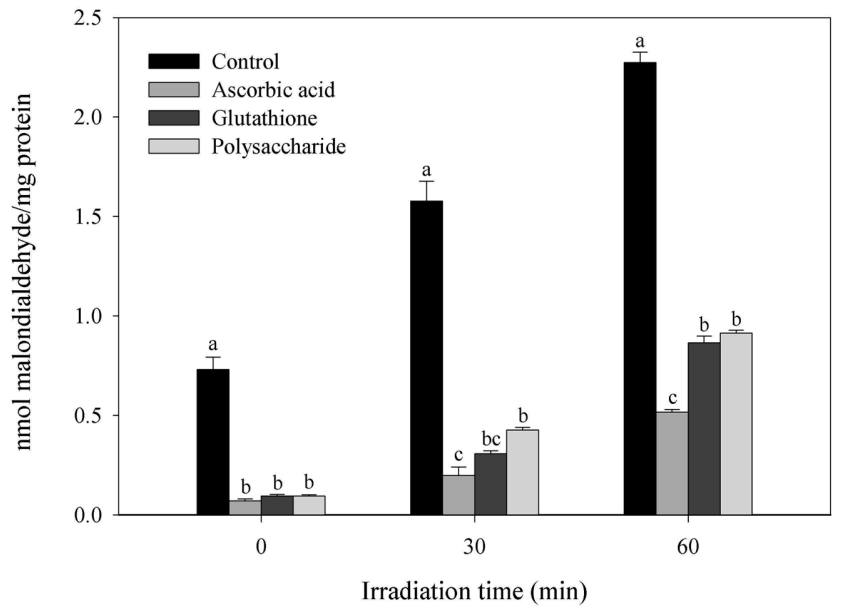

Fig. 3. Contents of malondialdehyde in UVB irradiated skin homogenates of mice fed vitamin $\mathbf{E}$ deficient. Values represent the mean \pm SD of three replications, and significant differences of samples were determined by Duncan's multiple test at the level of $p \leq 0.01$. The treated amount of antioxidant or PS was $2.5 \mathrm{mg}$ per petridish.

UVB for $60 \mathrm{~min}$ were $2.27,0.51,0.86$, and $0.91 \mathrm{nmol} / \mathrm{mg}$ protein, respectively. The results clearly showed that the ascorbic acid, glutathione and PS greatly inhibited the formation of malondialdehyde in skin homogenates during UVB irradiation, indicating its great protective activity against lipid peroxidation in skin during UVB irradiation. The protective activity of PS against the UVB induced lipid peroxidation was not significantly different with that of glutathione, a well known strong protective agent against skin damage under UV light $(p>0.05)$. The PS obtained from A.iwayomogi Kitamura stems may have very complex structure of PS backbone with chemically bound polyphenolic compounds. Song [1996] reported that PS extract of A.iwayomogi Kitamura reportedly has antihepatotoxic activities, antimutagenicity, immunomodulation, and anti-tumor activity [Koo et al. 1994; Song, 1996; Ahn et al, 2009]. The beneficiary activity of PS extract of A.iwayomogi Kitamura may be due to its antioxidative activity. Plant PSs have been reported previously to show strong antioxidative properties [Ramarahnam et al., 1995; Hu et al., 2003; Wang and Luo, 2007].

In brief summary, the present paper showed that PS extracted from A. iwayomogi Kitamura stems has a strong free radical scavenging activities in model systems. PS also showed exceptionally strong inhibitory effects against proteins oxidation and lipid peroxide on UVB damage in animal skin tissues. Taken together, we strongly expect that PS obtained from $A$. iwayomogi Kitamura stems may also reduce on UVB damage in human skin, and that the PS may be a promising source for preventing UV-induced epidermal cell injury and/or curing free radical tissue damage. Further confirmatory research, however, should be followed to positively identify this idea. 


\section{References}

Aeschbacher HU (1990) Antimutagenic/anticarcinogenic food components. In Mutagens and Carcinogens in the Diet, pp. 201216, Wiley-Liss, New York, NY.

Ahn BY, Jung MY, and Choi DS (2009) Protective activities of fractions of water extract obtained from Artemisia iwayomogi kitamura against oxidative stress-induced mutagenesity: Correlation with their reactive oxygen scavenging activity. Food Sci Biotechnol 18, 849-854.

Blair AL, Cree IA, Beck JS, and Hating MJG (1988) Measurement of phagocyte chemiluminenscence in a microtiter plate format. $J$ Immunol Methods 112, 163-168.

Boudard F, Vallot N, Cabaner C, and Bastide M (1994) Chemiluminenscence and nitrite determinations by the MALU macrophage cell line. J Immunol Methods 174, 259-268.

Choi DS, Kim SJ, and Jung MY (2001) Inhibitory activity of berberine on DNA strand cleavage induced by hydrogen peroxide and cytochrome c. Biosci Biotechnol Biochem 65, 452-455.

Chun HJ, Ahn BY, Han JH, and Woo WH (2001) Inhibitory effects of crude polysaccharide of water extract of Artemisia iwayomogi kit on melanin biosynthesis. J Yakhak Hoeji 45, 701-707.

Darr D and Fridovich I (1994) Free radical in cutaneous biology. $J$ Invest Dermatol 102, 671-675.

Dvies KJA and Goigberg AL (1987) Protein damaged by oxygen radicals are rapidly degraded in extracts of red blood cell. $J$ Biol Chem 262, 8227-8234.

Ginnopolitis CN and Ries SK (1977) Superoxide dismutase occurrence in higher plants. Plant Physiol 59, 309-314.

$\mathrm{Hu} \mathrm{Y}, \mathrm{Xu}$ J, and Hu QH (2003) Evaluation of antioxidant potential of aloe vera (Aloe barbadensis Miller) extracts. J Agric Food Chem 51, 7788-7791.

Jung MY, Kim, SK, and Kim SY (1995) Riboflavin-sensitized photooxidation of ascorbic acid: Kinetics and amino acid effects. Food Chem 53, 397-403.

Kim SS, Lee CK, Kang SS, Jung HA, and Choi JS (1997) Chlorogenic acid, an antioxidant principle from the aerial parts of Artemisia iwayomogi that acts on 1,1-diphenyl-2-picrylhydrazyl radical. Arch Pharm Res 20, 148-154.

Koo KA, Kwak JH, Lee KR, Zee OK, Woo ER, Park HK, and Youn HJ (1994) Antitumor and immunomodulating activities of the polysaccharide fraction from Artemisia selengensis and Artemisia iwayomogi. Arch Pharm Res 17, 371-374.

Korytowski W, Pilas B, Sarna T, and Kalyanaraman B (1987) Photoinduced generation of hydrogen peroxide and hydroxyl radical in melanins. Photochem Photobiol 45, 185-190.

Lee SB, Cho TS, Yoon KW, Lee JC, Lee SM, and Shim SB (1997) Hepatoprotective effects of extracts from Artemisia iwayomogi. $J$
Appl Pharmacol 6, 119-129.

Lindena J and Burkhardt H (1988) Separation and chemiluminescence properties of human, canine and rat polymorphonuclear cells. $J$ Immunol Methods 115, 141-147.

Liu F and Ng TB (2000) Antioxidative and free radical scavenging activities of selected medicinal herbs. Life Sci 66, 723-735.

Mills EL, Rholl KS, and Quiet PG (1980) Luminol-amplified chemiluminescence: a sensitive method for detecting the carrier state in chronic granulomatous disease. J Clin Microbiol 12, 5256.

Ohkawa H, Ohishi N, and Yagi K (1979) Assay for lipid peroxides in animal tissues by thiobarbituric acid reaction. Anal Biochem 95, 351-358.

Oliver CN, Ahn B, Moerman EJ, Goldstein SA, and Stadtman ER (1987) Age-related change in oxidized proteins. J Biol Chem 262, 5483-5491.

Raimondi L, Lodovici M, Guglielmi F, Banchelli G, Ciuffi M, Boldrini E, and Pirisino R (2003) The polysaccharide from Tamarindus indica (TS-polysaccharide) protects cultured corneal-derived cells (SIRC cells) from ultraviolet rays. $J$ Pharm Pharmacol 55, 333338.

Ramarahnam N, Osawa T, Ochi H, and Kawaishi S (1995) The contribution of plant food antioxidants to human health. Trends Food Sci Technol 6, 75-82.

Romero-gillette C, Aberdam E, Biagioli M, Massabni W, Ortonne JP, and Ballotti R (1996) Ultraviolet B radiation acts through the nitric oxide and cGMP signal transduction pathway to stimulate melanogenesis in human melanocytes. J Biol Chem 271, 2805228056.

Sakagami H, Aoki T, Simpson A, and Tanuma SI (1991) Analysis of immunomodulating cytokine mRNAs in the mouse induced by mushroom polysaccharides. Anticancer Res 11, 993-1000.

Song KW (1996) The phytochemical study of polysaccharide fraction from Artemisia speciess. MS thesis, Sungkyunkwan University, Seoul, Korea.

Wang ZJ and Luo D H (2007) Antioxidant activities of different fractions of polysaccharide purified from Gynostemma pentaphyllum Makino. Carbohydr Polym 68, 54-58.

Yen GC and Duh PD (1996) Antimutagenic effect of methanolic extracts from peanut hulls. Biosci Biotechnol Biochem 60, 16981700.

Yook CS (1989) Artemisia iwayomogi. In Coloured Medicinal Plants of Korea, p. 524, Academic Press, Seoul, Korea.

Zhou BR, Jin SL, Chen XF, Cai BX, Gao J, and Luo D (2008) Protection effect of the baicalin against DNA damage induced by ultraviolet B irradiation to mouse epidermis. Potodermatol Photoimmunol Photomed 24, 175-182. 